I Federal University of Santa Catarina (UFSC), Florianópolis, SC, Brazil

carlos.sell@ufsc.br

Carlos Eduardo Sell'

\title{
THE TWO CONCEPTS OF PATRIMONIALISM IN MAX WEBER: FROM THE DOMESTIC MODEL TO THE ORGANIZATIONAL MODEL
}

In focusing on an analysis of the concept of patrimonialism, the theme of this article is certainly far from insignificant: in fact, it involves one of the most important legacies in the sociological interpretation of Brazil. The category is found at the source of a historical sociology today considered classic, informing established works like those of Sérgio Buarque de Holanda ([1936] I995), Raymundo Faoro (1975), Simon Schwartzmann ([1975] I988), Maria Sylvia do Carvalho Franco (1976), Florestan Fernandes (2006) and Fernando Henrique Cardoso (2003), among others. In the contemporary context, far from having exhausted its persuasive power, patrimonialism occupies the very centre of the political debate on the role of the State (Lamounier, 20I4). In the wake of this second wave of studies, the thesis has been advanced that the theoretical appropriations of this tool and its application to the interpretation of Brazil's sociopolitical reality are misguided, constituting yet another example of our "out of place ideas" (Schwarz, I982). According to this line of argument, its original meaning has been distorted, either by the concept being utilized in an ahistorical form (Souza, 2015), or by the mobilization of a semantic sense divergent from the original (Campante, 2003).

The problem is that despite seeking to produce a more adequate interpretation of Weber, such critiques fare no better and simply end up reproducing the same problems. Nonetheless, it is not my intention to engage in a review of the supposed equivocations of this literature, still less to prob- 
lematize the empirical match between the concept of patrimonialism and Brazil's sociopolitical reality: it is not the intrinsic merit of this historicalsociological proposition that I call into question. Indeed, I believe it is necessary to free the discussion from this return to the sources and an attempt to delimit a 'true' meaning to this notion, as though concepts were unable to absorb semantic shifts that revive and reinvent their analytic relevance.

Leaving aside the negative task of critique, then, and concentrating solely on the positive conceptual determination, I intend to explore the discussion on the meaning of the thematic of patrimonialism in Max Weber's work, examining the findings available today in the specialized literature, especially in light of the exegetical discussion that has accompanied the process of republishing the complete edition of his work, the Max Weber Gesamtausgabe (MWG). Consequently, the hermeneutic locus of the present investigation is not Brazilian social thought, but the historical-critical exegesis of Weber's writings. The study will show that two sequentially ordered models of patrimonialism exist in Weber's work. In the final section, extrapolating from this observation, the article identifies some of its implications for our understanding of how the concept of patrimonialism was received in Brazil's intellectual and political debate. ${ }^{\mathrm{I}}$

\section{TRADITIONAL DOMINATION IN THE CONTEXT OF THE REDACTION OF ECONOMY AND SOCIETY}

The first step to understanding the concept of patrimonialism in Weber's thought involves turning to the author's texts, that is, to the context of his typology of forms of domination, in particular the traditional type. These forms, in turn, can only be correctly comprehended by taking as a parameter the ramifications of the long, complex and discontinuous redaction of the writings later entitled Economy and Society. This preliminary historical review of the oeuvre [Werkgeschichte] provides us with an initial reference point for comprehending the concept of patrimonialism in Weber.

\section{The evolution of Economy and Society}

The two volumes that historically became known under the title of Economy and Society comprise, in fact, just one part of a collection that proposed to investigate the relation between "the economy and the orders and social powers." His texts were not written with a rigid separation in mind between 'theoretical' and 'applied' works, as suggested by the classification introduced by Marianne Weber - the first editor of the work - and which became fixed definitively with the fifth edition coordinated by Johannes Winckelmann in I956 (the source of the translation currently available in Brazil). The logic that permeates the mass of texts left by Max Weber is not synchronic, as Marianne Weber presumed, but diachronic, as the current editors of the work 
have demonstrated (Weber, 2009). The studies realized to date have led to the conclusion that the process of redacting these texts is defined by two main phases, separated by the First World War. More than a 'work,' Economy and Society should be considered, on the contrary, a 'process' of investigation. ${ }^{2}$

Nonetheless, fate decided that the book that Max Weber would, very probably, have called 'Sociology' (Schluchter, 2016) remained incomplete, leaving us with various questions unanswered. Perhaps the most important of these concerns the extent to which the complex process of redaction and maturation of Economy and Society has theoretical repercussions on the content of Weber's thought itself. The point in question is whether we are dealing with just two phases of redaction or whether different epistemological conceptions also exist. More than a few voices (Lichtblau, 20I I and Norkus, 200I) make the claim for radical changes between the oldest texts in Economy and Society and those written after the First World War, when Weber had returned to teaching in Vienna (I9I8) and Munich (I9I9-I920). I do not intend to examine this complex dispute here, limiting myself to accept the position that appears to me as the most defensible, namely that there is no epistemological rupture in Weber's thought: refinements aside, his conception of sociology remains fundamentally the same. This does not mean that corrections and innovations should be ignored. Much the opposite. If we examine the extent to which the evolution of Economy and Society is directly reflected in specific theoretical aspects, we shall see that the shifts are far from negligible, as I show below.

\section{The evolution of the sociology of domination}

An attentive reader will already have noted that there are two chapters - both on the subject of domination - that apparently repeat themselves in the two volumes of the Brazilian edition of Economy and Society. The first of these (Chapter 3), located in the first volume of the Winckelmann edition, is entitled "The types of domination" and comprises the most recent version to be written or updated by Weber. The second (Chapter 9 of the second volume in the Brazilian edition), incidentally much longer, belongs to the so-called old part of Economy and Society and was written by Weber between I9Io and I9I3. During the latter period, the thinker announced with considerable pomp that he possessed "a complete sociological theory of the State," as expressed in a letter to his editor, dated I3 June I9Io (Weber, 2003: 53). At first sight, the differences between these two texts is merely quantitative, at least if we adhere to the organizational schema established by Marianne Weber, who added a series of subtitles to Max Weber's manuscripts absent from the original. As the new layout of the MWG shows, though, the older part of the sociology of domination in Weber is composed of eight independent manuscripts that received the following titles: Domination, Bureaucratism, Patrimonialism, Feudalism, Charismatism, Transformation of Charisma, Mainte- 
nance of Charisma, State and Hierarchy. Nothing, therefore, reminiscent of an integrated, systematic and coherent order based around the three principles of legitimacy (legal, traditional and charismatic) with which we have become accustomed.

Indeed, the novelties do not end there. The editors of Number 5 of the volume of Economy and Society (MWG) that collects his writings on domination from the pre-war period succeeded in identifying eight distinct moments during which Weber dedicated himself, with varying degrees of attention, to the presentation and development of his sociology of domination. The first detailed exposition of this theme is found in a text entitled "Einleitung" [Introduction], written in I9I $5,^{3}$ though Weber had already set out this typology in a work plan sent to Paul Siebeck in June I9I4. This is followed by the extended chapter from the earlier part of Economy and Society, with its eight topics, which remained unfinished. The topic was picked up again by Weber after the Great War, as documented in the version of this theme contained in the new part of Economy and Society and in another three texts. The first is a lecture given in I9I8, in Vienna, with the title "Problems in the sociology of the State," whose main novelty is the introduction of a fourth kind of legitimacy - democratic - an idea that would later be dropped. Another exposition follows that can be located in Politics as a profession from I9I9, and some annotations for use in classrooms from I920. Finally, we also have a text published by Marianne Weber in 1922, but whose dating is uncertain, entitled The three pure types of domination.

What is retained and what changes over the course of these eight presentations? To respond to this question, we have to examine it from two angles. At a general level, the question is to what extent the conceptual architecture of the sociology of domination as a whole itself transforms (or not) over this process of reflection. From a more specific angle, it is important to investigate the extent to which aspects internal to the three types of domination are altered.

In terms of the general schema, the specialists (Breuer, I994 and 2006, and Schluchter, I985) agree about one point. The Weberian trilogy of types of domination cannot be reduced to its historical dimension insofar as it implies a linear series of stages, whose starting point is the charismatic type and whose end point is the legal-bureaucratic model (Hanke, 200r: 34). Nothing more alien to Weber than a teleological type of sequence. In postulating a science that seeks to determine the general rules of events, the concepts of Max Weber cannot be comprehended merely as historical descriptions, but as ideal types of a sociological kind. Taking the legal-bureaucratic type as a parameter, Weber discusses the rational character of the modern mode of domination, and it is this theoretical aspect that forms the sociological core of his study (Hanke, 200I: 35). Weber's endeavour is primordially sociologicaltypological rather than historical-evolutionary. This does not mean that the 
Weberian trilogy is merely statistical or lacking a dynamic conception of sociopolitical processes. Schluchter (1988: 544-549) observes that, in this case, it is the charismatic type which is located at the centre of his theoretical model, since, through this type, Weber identifies two processes of routinization that can occur through its 'traditionalization' or "legalization", or still further through the "objectification" of the charisma.

Nonetheless, while the specialists concur thus far, disagreement emerges over the criteria that analytically structure the Weberian theory of domination. On this point, Edith Hanke (200I) argues that the two chapters on domination in Economy and Society are inconsistent and in fact reveal a clear theoretical change from one version to the other. In his first phase, Weber had yet to refer to a typology based on criteria of legitimacy, an ordering principle that, she argues, was introduced only in his mature phase of reflection. This view is challenged by Wolfgang Schluchter (I988) who, while acknowledging the imprecisions in Weber's work, sees no substantial theoretical contradiction between the thinker's two phases of production, which allows us, he argues, to read Weber's writings on domination as internally consistent. ${ }^{4}$

This interpretative polemic calls attention to a more important point, namely, the heuristic criteria that form the basis of the distinct types of domination (Maurer, I999). Although much of the secondary literature (Bobbio, 2003) tends to give more emphasis to the role of the principles of legitimacy as a conceptual substrate of the different types of domination, its organizational dimension cannot be ignored. The Weberian sociology of domination is founded on two independent and complementary pillars: cognitivesymbolic and structural-organizational. The first refers to the set of shared beliefs that found the acceptance of relations of authority (legitimacy), and the second to the nature and ownership of the means of administrating power (organization). Domination is simultaneously constituted by legitimate beliefs (distinguished by whether they are personal or impersonal, routine or extraordinary) and by an administrative apparatus (distinguished by the variations in the means and ownership of the administration of domination). Ignoring this second element leads to a cultural-idealist reading of the Weberian theory of domination, while forgetting the first leads to structuralinstitutional reductionism. Spirit and form, or legitimacy and organization, are the two axial principles of Max Weber's political sociology, the former internal, the latter external.

\section{The evolution of the traditional type of domination}

While at a general level we can, without ignoring the corrections and refinements made, reject the thesis of an epistemological rupture in Weber's writings on domination, when we descend to the level of conceptual detail, the differences become clearer. A comparative analysis of the two versions of the tra- 
ditional form of domination in Economy and Society allows us to identify various such changes. The first point concerns the analytic criteria used to confect this ideal type. In the earlier version, Weber advances the thesis that patriarchalism is the prototype of every traditional form of domination, the other subtypes being merely later developments of this original matrix. When we jump from this initial version to the later one, the analytic framework of domination is reshaped.

In first place, the ideal subtype 'feudalism' loses its place within the traditional form in order to be placed only after charismatic domination as a mixed type, since "from it can emerge a structure of association of domination distinct both from patrimonialism and from charismatism" (Weber, 2013, MWG I/23: 5I3). For this reason, feudalism ceases to be considered a 'particular case' of patrimonialism.

Second, the prototypical role of patriarchalism is abandoned, and the subtypes (or internal types) of traditional domination become distinguished by organizational criteria - that is, based on the existence and nature of the administrative apparatus. As a consequence of this change, the concept of patrimonialism, which previously had a derivative role, comes to perform the determinant role in characterizing the organized administrative forms of traditional domination. It is at this level that Weber modifies the comprehension of the concept, transiting from a domestic to an organizational model. The 'family' ceases to be the historical-genetic starting point and relinquishes its place to the structural criterion of 'ownership' of the means of administration as the basis for defining patrimonialism.

As a result of this factors, the terminology that differentiates the subtypes of traditional domination becomes reorganized. Hence rather than the linear-evolutionary sequence (from patriarchalism to patrimonialism and from the latter to feudalism) encountered in Weber's earlier theorizations, the author adopts a new arrangement of categories systemized according to two qualitatively distinct subsets located within traditional domination: on one hand, the primary types of patriarchalism and gerontocracy, and, on the other, patrimonialism. ${ }^{5}$

Undoubtedly, this is not a question merely of stylistic corrections, since what we encounter ultimately are not just new criteria but new concepts. The typical-ideal organizational schema of the traditional form of domination, although not implying exactly a rupture with the earlier investigation, was profoundly reworked in terms of its form and content. The implications of these developments for Weber's understanding of the concept of patrimonialism, and especially for how he pursues his historical-comparative analyses of this phenomenon, are examined in detail in the following sections. 


\section{PATRIMONIALISM AS A CONCEPT}

Viewed superficially, the concept of patrimonialism does not appear to have undergone any change during the redaction of Economy and Society. It is present both in the older versions and in the post-war revision, which could lead us to believe that only its positioning within the general schema of domination was altered. However, a closer examination reveals that as the concept matured, Weber lent it new meanings and scope: it is not just its place that is modified, but also both its content and its historical use (Zingerle, I972; Bruhns, 20II and Breuer, 200I).

The motives leading to this change are left unexplained by Weber himself (Weber, 2013, MWG I/23: 484), prompting us to consult the theoretical sources to which he turned. In the first versions of his study of domination, Weber adopted Carl Ludwig Haller's concept of patrimonialism, which, in his work Restauration der Staatswissenschaft, published in I816, discriminated three forms of State: patriarchal, military and spiritual. In the schema, patrimonialism is taken to be a historical evolution of patriarchalism and, as such, is not distinguished from the latter qualitatively. For its supporters, the foundation of politics is the pater familias. This reading was challenged by Georg von Below who criticized Haller for having reduced the Medieval State to the private form of domestic relations, thus confusing the spheres of public and private law. Weber became aware of Below's text (Der deutsche Staats der Mittelalter, published in I9I4) and agreed with his critique, but nonetheless continued to use the term patrimonialism, as he himself explains in a letter dated 2I June I9I4 (Weber, 20I3, MWG I/23: 723-725) written to the author:

Terminologically, I shall have to maintain the concept of 'patrimonialism' to characterize determined types of political domination. However, the absolute disjuncture between domestic, corporeal and seigniorial power, on one hand, and political domination on the other - in relation to which no other criterion of distinction yet exists, save for what the former is not (military and juridical power) - I hope is sufficiently accentuated. The broader thesis of his book has acquired a remarkable validity. What I wish to do is simply test whether this distinction is as old as history itself.

The terms could not be clearer. The concept of patrimonialism remains, but it is now completely separate from private powers. What impact did this decision have for the meaning of the concept?

\section{Domestic model}

During the initial phases of his research, in fact, Weber worked with the thesis that patrimonialism is an extension of the "patriarchal structure of domination," considered by him to be the most important form of pro-bureaucratic domination (Weber, 2005, MWG I/22-4: 247). Hence it comprises a prototypical structure or "the formally most consistent authority structure 
that is sanctified by tradition" (252). Taking this as a starting point, Weber examined "that form of domination which developed on the basis of the oikos and therefore of differentiated patriarchal power: patrimonial domination" (254). This is why patrimonialism would be merely a "special case of patriarchal domination" (257), or put otherwise, a "domestic authority decentralized" (257). Following this reasoning, the "personal relations" (247) that characterize the patriarchal structure continue to govern patrimonial domination, although the process of transition from the family to the Oikos leads to an important change: the curbing of the arbitrariness of the domestic master through the submission to traditional rules. But this does nothing to alter the essential fact that patriarchal domination and patrimonial domination are both equally forms of 'domestic power' [Hausgewalt] (254).

Continuing this genetic-evolutionary line of argument, Weber also identifies a third moment of differentiation, represented by the emergence of full-blown political associations: "We shall speak of a patrimonial state when the prince organizes his political power over extrapatrimonial areas and political subjects - which is not discretionary and not enforced by physical coercion - just like the exercise of his patriarchal power" (Weber, 2005, MWG I/22-4: 26I). From this emerges 'estate' patrimonialism, explained as follows: "The typification and monopolistic appropriation of the powers of office by the incumbents as members of such a legally autonomous sodality created the estate-type of patrimonialism" (290). ${ }^{6}$ At the end of the sequence is the 'estate-type State,' since, insofar as feudalism represents an extreme case of estate patrimonialism (380), this form of State can be defined as "a case-bycase collusion between the different holders of power" (4II). In the earlier version of Economy and Society, the estate-type State is a synonym of feudalism.

In the second version of the theory of domination, this conception is entirely rethought, and instead of continuity, Weber insists on marking the radical discontinuity between the patriarchal type and the patrimonial type. In his own terms, "Both forms of domination [patrimonialism and sultanism] are distinguished from elementary patriarchalism by the presence of a personal staff" (Weber, 2013, MWG I/23: 476). This comprises a decisive shift and the confusion or mixture between the domestic model of patrimonialism, present in the first phase of his work, and the organizational model of his later writings has proven to be the main Achilles's heel of the secondary literature, leading to diverse inconsistencies (as in Zabludowsky, I989).

In the following topics I seek to go beyond these equivocations, concentrating on the systematic presentation of the concept of patrimonialism during the mature phase of Weberian sociology. In embarking on this task, Siegfried Hermes (2003) reminds us that the theme of patrimonialism should not be examined in isolation, given that it invokes the core topics of Weber's comprehensive sociology, beginning with the central problematic of his thought, the 
thesis of rationalization (Sell, 2013). From the epistemological viewpoint, in turn, the concept of patrimonialism needs to be read in light of the theory of the ideal type, thus invoking its methodological dimension. Following the suggestion of Hermes, my aim is, at a formal level, to clarify the status and significance of patrimonialism as a concept and, at a material level, to investigate how Weber used it as a tool in his sociological-comparative analysis.

\section{Organizational model}

I begin with the abstract level of categories, examining patrimonialism as an ideal type, or better, as a 'subtype.' In order to guide this task we have to take as a parameter the two axes around which Weber formulates his types of domination: legitimacy and organization. Generally speaking, traditional domination rests "on an established belief in the sanctity of immemorial traditions and the legitimacy of those exercising authority under them" (Weber, 20I3, MWG I/23: 453), or, in other words, it is defined from the perspective (belief) of the dominated. But in this detailed exploration of traditional domination, such markers do not operate in isolation, since other analytic elements are added that determine and specify them. In the process of detailing his account, Weber utilizes the following criteria: the ruler's binding to tradition and his capacity to monopolize the means of administrating power (i.e. the relation between ruler and administrative framework). The result is that in terms of the criterion of legitimacy we have the "double sphere" (Weber, 2013, MWG I/23: 468) of action materially bound to tradition or the action of the master materially free of tradition; while in terms of the organizational criterion (when the administrative framework exists), what matters is the capacity of the dominant to monopolize the means of administrating domination. Both criteria can be represented in the form of a continuum, distributed as follows:

Legitimacy axis | Weight of tradition

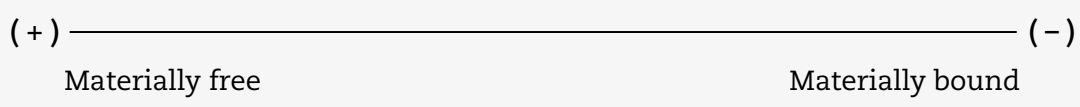

Organizational axis | Degree of appropriation of the means of control

$(+)$ $(-)$

Total

Partial

Figure I

Traditional domination 
By applying these analytic criteria, we obtain different subtypes within the (general) type of traditional domination. These subtypes are themselves divided into two qualitatively distinct subsets, depending on the existence or otherwise of an administrative framework. The first subset is divided into primary patriarchalism and gerontocracy, while the second is patrimonial domination. The introduction of the organizational element alters the dynamic of the reference to tradition, as well as modifying the type of relationship between dominant and dominated.

Let us turn first to the "primary types of traditional domination," a situation negatively defined by the absence of an administrative framework. The first of these types, gerontocracy, is defined by the fact that domination "is in the hands of elders" (Weber, 20I3, MWG I/23: 475), while primary patriarchalism concerns the "situation where, within a group (household) which is usually organized on both an economic and a kinship basis, a particular individual governs who is designated by a definite rule of inheritance" (475). The structural difference between these primary types is linked to the nature and scope of the social formations in which domination is exercised, namely: household and economic units, in the case of primary patriarchalism, or broader units, in the case of gerontocracy. However, these differences are minimal and none of this alters the two central elements of these first subtypes. On the question of the mode of relationship between individuals, in the case of both patriarchalism and gerontocracy - since no administrative framework exists - the members are considered 'comrades' [Genossen]. On the question of tradition, in turn, the distinctive trait is that it confers primacy to the members themselves with domination exercised in their own interest, meaning that there is no free appropriation of this right by the master. Consequently the master "is thus on his part strictly bound by tradition" (475).

As we shift from the primary types (without an administrative framework) to the level of forms of traditional domination endowed with an administration and a military force as "purely personal instruments of the master" (Weber, 20I3, MWG I/23: 476), this evolution is taken to have had a qualitative impact both on the mode of relations between individuals and on the role of tradition. One outcome of this systemic complexification is the change in the nature of the relations between rulers and ruled, with the latter assuming the status of 'subjects.' As for the role of tradition: "Previously the master's authority appeared as a pre-eminent group right, now it turns into his personal right" (476). What, though, makes the analysis of the subtypes of administratively organized domination so complex is that Weber analyses separately the variations existing both in the relationship between the ruler and tradition and in the relationship between ruler and administrative framework.

We can begin with the first criterion, which concerns the legitimacy axis. In this two situations may become manifest. The first is 'patrimonial 
authority,' which he defines as existing "[we]here domination is primarily traditional, even though it is exercised by virtue of the ruler's personal autonomy" (Weber, 2013, MWG I/23: 476). Next he defines sultanism as patrimonial domination which, with its forms of administration, "operates primarily on the basis of discretion," detached from tradition (476). Despite considering the differences to be fluid, Weber insists on the fact that "the sultanist form of patrimonialism [...] is completely disconnected from tradition," or in other words, in it "the sphere of the arbitrary and free graces developed to an extreme" (477). Here it is important to note that despite sometimes employing the simple contrast between "patrimonialism and sultanism," when he details the analytic meaning of these concepts, 'patrimonial domination' and 'sultanist patrimonial domination' are clearly distinguished. Both subtypes are forms of patrimonialism and what differentiates them is merely the extent of the master's arbitrariness in relation to tradition.

The symbolic dimension of the bond with tradition should not be confused with the structural dimension of the distribution of the means of material control of power, that is, with the organizational axis of his model. In this context Weber stated: "Estate-type domination is that form of patrimonial authority under which the administrative staff appropriates particular powers and the corresponding economic assets" (Weber, 20I3, MWG I/23: 477). He proceeds to detail the variations concerning this aspect, differentiating between "appropriation by the master" and "estate-type appropriation" (479) through the criterion of access to the resources of power. Hence: "In the case of pure patrimonialism, there is complete separation of the functionary from the means of carrying out his function. But exactly the opposite is true of the estate-type of patrimonialism. The person exercising governing powers has personal control of the means of administration - if not all, at least of an important part of them" (479). He adds that: Historically there has never been a purely patrimonial state" (484). Here too both subtypes are forms of patrimonialism, and what differentiates them is the degree of appropriation of the means of administration.

The complexity of the Weberian concept of patrimonialism derives from the fact it is bidimensional and needs to be analysed in relation both to the symbolic aspect of legitimacy and to the structural aspect of organization, as shown in the figure on the next page.

Patrimonialism was always a fundamental (sub)type in Weber's political theory. In the primary phase of his work, he understood patrimonial domination to be a genetic derivation of patriarchal domination and estatetype patrimonialism as a very particular case of which feudalism, in turn, was a derivative. In the second phase of his writings, Weber focuses on the organizational dimension and patrimonialism assumes a determinant place in the characterization of complex or administratively structured forms of 
traditional domination. In this version, the concept is differentiated along two analytic axes: in terms of legitimization, we find patrimonialism and sultanist patrimonialism; while in terms of organization, pure patrimonialism is opposed to estate-type patrimonialism.

\begin{tabular}{llll} 
Legitimacy & & Organization & \\
Pure type & Subtype & Pure type & Subtype \\
Patrimonial & Sultanist & Pure & Estate-type \\
$\begin{array}{l}\text { domination } \\
\text { (pure) }\end{array}$ & domination & patrimonialism & Patrimonialism \\
\hline
\end{tabular}

Figure 2:

Patrimonialism: pure type and subtypes

\section{PATRIMONIALISM IN COMPARATIVE PERSPECTIVE}

The study of patrimonialism in Weber's work cannot be limited to its internal semantics, ignoring its pragmatic-analytic function. The Weberian schema does not remain solely at the level of abstraction, bearing in mind that it amounts to an instrument through which he aims to capture, concretely, the dynamic through which the forms of rational domination that characterize western modernity are constructed. Although formal, ideal types serve as instruments for apprehending real empirical-social processes. They are not depictions of an externally given reality and much less should they be simply applied in mechanical form. For this reason, at the level of empirical analysis Weber frequently constructs 'mixed types' [Mischtipen], retaining a fine sensibility towards the ever complex and contradictory nature of reality. This rule also applies to the case of the patrimonialism subtype, as we can perceive by the combined nuances in which Weber employs the term: patrimonial bureaucracy, arbitrary patriarchalism, landlord patrimonialism, hierocratic patrimonialism, political patrimonialism, military patrimonialism, princely patrimonialism, patrimonial association, patrimonial serfdom, etc.

On this topic I seek to reconstruct Weber's sociological-empirical analyses, highlighting the comparative nature of his approach. It is important to pay attention to the way in which he contrasts distinct cultural experiences - that is, how he uses and compares the concepts of patrimonialism (China) and feudalism (Europe) to characterize the typical traits of the modern West. To facilitate the analysis, I analyse separately the historical-comparative 
descriptions of patrimonialism developed in the old part of Economy and Society and those analyses found in the writings on the comparative sociology of religion, since the latter are chronologically related to his more recent version of domination.

\section{The patrimonial state in the earlier version of Economy and Society}

To understand the place occupied by the concept of patrimonialism in the old version of the sociology of domination of Economy and Society we need to consider the Patrimonialism and Feudalism manuscripts in conjunction. The main reason for this is that, in this phase of his production, Weber considered feudalism to be a particular case of patrimonialism, as, indeed, he makes explicit in this passage: "feudalism is a marginal case of patrimonialism that tends toward stereotyped and fixed relationships between lord and vassal" (Weber, 2005, MWG I/22-4: 380).

To historically illustrate the main types of patrimonialist administration (Weber, 2005, MWG I/22-4: 32I), Weber explored four cases and, to characterize them, considered in particular the prince's struggle against the interests of the administrative framework, the territorial lords and the local political forces. From these factors emerges a continuum that spans from centralization to decentralization. Ancient Egypt is the classic case in which an absolute centralization exists and, in this sense, it amounted to "one single domain of the royal oikos" (326). Scribes and army are patrimonially linked to the pharaoh, and the rest of society is employed in the construction of public works. We can also speak of a "state of forced labour" (32I). Weber considered the Chinese Empire to be an "essentially different" case (326), since although it was also highly centralized, the emperor needed to ally himself with the bureaucracy (estate of the literati) to impose his power over the local (feudal) clans. While the Egyptian and Chinese cases are characterized by centralization, centrifugal forces predominate in the historical examples of England and Czarist Russia. In the Russian case, the administrative posts were appropriated by the nobility or aristocracy, weakening local powers. The result was a combination of "estate-type patrimonialism with territorial nobility" (463). Finally, in England the solution found for the royalty to weaken the power of the territorial lords (barons) was to strengthen local powers through the socalled justices of the peace (35I). The result was a combination of "combination of patrimonialism of the estate type with a pure type of autonomous administration by honoratiores, and it tended much more toward the latter than toward the former" (359). The four cases examined here demonstrate that at the centre of the Weberian analysis is the essentially unstable of character of patrimonialism, marked by a strong entropic tendency.

The feudalism represents a contrary tendency: "The structure of feudal relationships can be contrasted with the wide realm of discretion and the 
related instability of power positions under pure patrimonialism" (Weber, 2005, MWG I/22-4: 380). But despite being derived from patrimonialism, the schema is dichotomous since while patrimonialism is considered arbitrary and unstable, feudalism has limited powers and is stable. In feudalism, the duty of personal loyalty becomes detached from the filial relations of the domestic community, "and on its basis a cosmos of rights and duties has come into being" (35I). Due to this contrast, while patrimonialism is characterized by relations of dependency, the feudal bond is characterized by "free contractual relations" (4IO). Weber takes a special interest in vassalage as a subtype of feudalism, which he identifies as a specifically western form of feudal relations.7 Politically, feudalism comprises a form of division of powers (Montesquieu) and its fixation by legal regulations is the origin of the "estate-type State" (4II), which prevailed in the European Middle Ages.

In the older version of his sociology of traditional domination, Weber established an intrinsic categorical link between feudalism and patrimonialism, with the former taken as an extreme case of the latter: that is, as a specific and concrete historico-social form of estate-type patrimonialism. From the sociological-empirical viewpoint, patrimonialism is considered an unstable political order, while the singular and decisive characteristic of feudalism is stability. In patrimonialism, the struggle between the prince and centrifugal forces is never fully resolved, while in feudalism they encounter a point of equilibrium. Finally, from the historical-comparative viewpoint, Weber's analysis exhibits a strongly dualist nature insofar as it rigidly contrasts the Eastern experiences of patrimonialism in Egypt and China with the feudal experience of Western Europe.

\section{Patrimonial bureaucracy in Confucianism and Taoism}

Weber's studies on the theoretical and empirical relations between feudalism and patrimonialism change in the post-war writings (second version of his sociology of domination). From the theoretical viewpoint, in addition to the corrections made to the concept of patrimonialism, already described earlier, Weber definitively cuts the analytic links that previously tied the concept of feudalism to that of patrimonialism. In his new conception, feudalism is considered a distinct subtype of both patrimonialism and pure charismatism. The classification of the historical types of feudalism is also simplified with Weber now distinguishing between two basic forms of feudal relations: the feudalism of fiefs and the feudalism of prebends. From the empirical viewpoint, these innovations enable Weber to move beyond a dichotomous use of the categories of patrimonialism and feudalism in order to typify historical-concrete realities: the feudalism of fiefs is typical of Western Europe, but it is also possible to find prebendary feudalism in China. Along the same lines, he does not deny the bureaucratic nature of the Chinese empire. There are two 
inverse movements, therefore: at a theoretical level, the conceptual distinctions are accentuated, while at an empirical level the similarities increase.

During the second phase of his work, Weber shifts from his concrete historical-cultural descriptions of Economy and Society to his Collected Essays on the Sociology of Religion, in which he compares the forms of rationalization encountered in China and India with modern Western rationalism (Sell, 2013). In Hinduism and Buddhism, the theme of patrimonialism is explored in the context of his reflections on the caste responsible for the exercise of political power: the Kshatriya (Weber, I996: I28-I48). In his analysis, the predominance of the Brahmins in the Hindu social system already demonstrates the weakness of the political system which, moreover, was unable to attain a degree of unity around a prince. In this context, patrimonialism is manifested in the fact that the local powers remained to a large extent in possession of the means of controlling political power (I45).

This reality is fairly different in Confucianism and Taoism where the theme of patrimonialism receives special attention. The chapter dedicated by Weber to the analysis of the Chinese patrimonial structure (entitled Feudal state and prebendalism) can be divided into two major parts. ${ }^{8}$ In the historical part (I989: I80-I93) Weber describes the transition process from Chinese feudalism to the patrimonial-bureaucratic state, which peaked under the reforms introduced by Shih-Huang Ti, in 22I BC, as well as the countermovements that sought unsuccessfully - to restore the ancient feudal order. It is fundamental to note that now Weber accepts the existence of Chinese feudalism, although its base is not formed by territorial lords (as in the West), but by clans with charismatic characteristics. In the second part (194-226) he examines the structure of political organization under the Chinese empire, especially the division of powers between central government and provincial governments, as well as the distribution of powers in relation to the provision of services (public works and military service) and, in particular, to the distribution of taxes (which are partly appropriated by bureaucrats as prebends).

From the viewpoint of their empirical accuracy, Weber's historical descriptions have been subject to harsh critiques, most of whose authors (Bünger, 1977; Hamilton, I984 and Lin, 1997) argue that the limitations to the sources used had led him to make diverse factual errors, although on this point there are more than a few dissenting voices (Schmidt-Glintzer, 200r: 223-234). At any rate, it is the sociological-analytic, rather than strictly descriptive, aspects of this study that really matter here and, in this respect, the interpreters end up opting for different emphases.

One group of authors (Egger, 2006; Hermes, 2003 and Zingerle, 1972) highlights the diachronic aspect of the schema, showing how, in the analysis of the Chinese case, a cyclical element is present in which feudalism and patrimonialism historically alternate. Schluchter (I983 and 1988), on the other 
hand, approaches the structural dimension of the theme, demonstrating how Weber in his characterization of the Chinese case makes use of hybrid typicalideal categories. The Chinese reality is not defined through a single ideal type, since it possesses both charismatic elements (emperor) and feudal elements (prebends), and even its basic political structure involves a dual type: in other words, it comprises a patrimonial bureaucracy. The Chinese political structure is patrimonial since, on one hand, the mandarins are owners of the means of administration, in particular of the taxes collected. On the other hand, it also possesses a bureaucratic component, given that the functionaries are recruited through a rigorous exam system and, at the same time, need to migrate from time to time from one province to another. This component of separation between functionaries and the means of administrative control approximates the Chinese case to the ideal type of bureaucracy. ${ }^{9}$

\section{A final hypothesis: patrimonialism in the Brazilian debate}

The category of patrimonialism, presented here methodologically as a subtype within the traditional mode of domination, is the central theoretical component of the traditional form of domination. In the initial version of his studies, patrimonialism was conceived as a prolongation of domestic power in the context of political relations (individual domestic model), but in his later use Weber redefined patrimonialism in accordance with two distinct criteria: the degree of intensity of the bond between rulers and tradition, and the degree of control of the rulers over the instruments of administrating power (a dual organizational model). While the first model adopts a historical-linear logic, the second is guided by an institutional-organizational approach. These epistemological changes do not leave unscathed his historical-comparative analyses, since while in the first phase, adopting the criterion of centralization or decentralization, Weber radicalized the differences between Chinese patrimonialism and European feudalism, in the later writings the emphasis on the combined nature of patrimonial bureaucracy prevails. Hence there is a shift from an antinomic model to a hybrid model. Overall, the Weberian analysis of patrimonialism undergoes an epistemological shift of a declining formal typification. At a conceptual level, the pure types are specified or detailed with the introduction of analytic variables that result in new subtypes. At an empirical-applied level, such subtypes are again redefined in order to characterize historical individualities, resulting in mixed types.

The lack of attention to the complexity of this methodological construction and, above all, the pure and simple mixture of writings from different phases of Weber's work has hindered comprehension of how this idea evolved in his political sociology. Whatever the case, it is not a primary goal of the present investigation to widen the range of discussions towards an exegetical reception of the idea of patrimonialism in the Brazilian intellectual con- 
text. Indeed the present article emphasizes the received (Max Weber) much more than the process of receiving his ideas. Nonetheless, considering the differences between these two conceptions identified in Weber's work, one hypothesis deserves to be considered. In Brazil too, these two models (typical-ideal) of patrimonialism, each referring us, by affinity, to different phases of Weber's thought, circulate in the academic-political debate. The difference between them is not related solely to the sociological locus in which the same Brazilian patrimonialism is supposedly rooted - society or State (Werneck-Vianna, I999 and Souza, 20I5). It is essential not to lose sight of the fact that these versions do not share the same understanding of the meaning informing the concept. We are not dealing with one patrimonialism whose roots can be situated in two alternative social spaces: family or State, values or institutions. It is not just a question of genesis, but also one of definition: not just from where it is born, but what the phenomenon actually signifies.

In line with this dichotomy, then, we can speak on one hand (and in tune with Weber's domestic model from the first phase) of the 'societal-patriarchal' conception of patrimonialism, which is defined by the thesis of the corrosion of the public character of the State by the personalist logic present in domestic-private relations (Holanda, I995). On the other hand (and in affinity with the organizational model of late Weber), we also have the 'liberal-institutional' conception in which the concept of patrimonialism is mobilized in order to identify the historical barriers that blocked the institutionalization of political-economic liberalism in Brazil (Faoro, I975). In this model, patrimonialism is ultimately defined as statism. Critique of antistate personalism and critique of antiliberal statism; excess of personalism in the former, lack of civil society in the latter; an affective-cordial orientation in one, an orientation towards material rationality in the other - hence the synthesis of the analytic dualities present in the conceptions of patrimonialism that, sometimes in parallel, sometimes symbiotically, circulate in the Brazilian debate. They differ in terms of not only the definition of Brazil's dilemmas, but also their diagnoses and prognoses, although recently the societal-personalist version has tended to absorb the state-liberal version, as though the public/private dichotomy were the common link to both, which I believe not to have been exactly the case.

Both versions seek legitimacy by drawing support from the ancestral authority of Weber's writings, although he himself had abandoned a conception of patriarchal patrimonialism, founded on domestic power. At the same time, it is also a fact that these two readings (societal-personalist and liberal-institutional) dislocate, albeit the first more and the second less, the category of his original theoretical foundation - the sociological problematic of rationalism - and provide it with new hermeneutic frameworks, eminently 
political-normative in character: namely, the semantics of a republican-communitarian resonance contained in the 'public/private' opposition, on one hand, or the clearly liberal semantics which opposes "individual and State" on the other.

These differences in understanding and especially in the use of the concept of patrimonialism to understand the Brazilian reality have already been picked up by other works dedicated to researching the uneven reception of Max Weber's sociology in our intellectual context, to use the felicitous expression of Glaucia Villas Bôas (20I4). Citing these, albeit briefly, will help us size up the conclusions that follow. André Botelho (2013), for example, rightly turns to Maria Sylvia de Carvalho Franco's critique of the appropriation of this concept by Fernando Henrique Cardoso in his work Capitalismo e escravidão no Brasil meridional [Capitalism and slavery in southern Brazil]. Pointing to the author's somewhat unrigorous and ahistorical use of the notion, Franco directs her critique precisely at the way in which the Escola Paulista de Sociologia privileged the conception of patrimonialism of the early Weber (domestic model), locating it in the societal dimension of social stratification. In the opposite direction, and making use of her own concept of 'personal domination,' she rejects understanding the forms of political relationship prevailing in the coffee civilization via the concept of patrimonialism (of Weber from the first phase), thereby showing herself to be in tune with the way in which Weber reformulated the concept in the final phase of his work (organizational model). Just as in the opposition of Holanda versus Faoro, here different understandings are produced of what patrimonialism is and, principally, about its role in explaining Brazil.

Obviously the sociohistorical investigation of how the concept of patrimonialism was received in the Brazilian debate merits a much longer and more detailed development, but given the already excessive length of this study, I shall restrict myself, in this final part, merely to these brief pointers, aware that the subject will still need to be deepened. This later study would also aim to show, among other things, the combined or mixed uses of the two conceptions of patrimonialism identified here. Nevertheless, the focus of this article was to show the evolution of the concept of patrimonialism in the work of Max Weber, clearing the way to understanding the implications of this difference (between the domestic model and the institutional model) in how it was received here. ${ }^{\text {Io }}$

Finally, it is worth recalling that the process through which ideas circulate, despite all the transitions and dislocations, cannot be considered illegitimate. Rather, they represent conceptual appropriations and rereadings that respond to the theoretical and political demands and problems of our time and our reality and, unless we desire an infertile orthodoxy, are valid theoretical constructs. However this does not exempt us from understanding 
how, in response to our interests and taking into account the passing selection and appropriation of ideas, they are remodelled and adapted, giving rise to a Brazilian language of thought legitimately inspired by the political sociology of Max Weber.

Received on 05/03/2017 | Revised on 20/04/2017 | Approved on 21/04/2017

Carlos Eduardo Sell has an undergraduate degree in philosophy and a doctorate in political sociology. He currently teaches on the Postgraduate Program in Political Sociology at the Federal University of Santa Catarina (UFSC). He was coordinator of the ANPOCS Social Theory Group in 20142016 and has coordinated the Sociological Theory Group of the Brazilian Sociology Society (SBS) since 20I3. He conducted postdoctoral research at the Heidelberg Max Weber Institute of Sociology (Germany), with which he continues to work closely. His research theme is German social theory, focusing especially on Max Weber. In 2013, he published the book Max Weber e a racionalização da vida e Sociologia clássica: Marx, Durkheim e Weber, today in its seventh edition. 


\section{NOTES}

I This article was written in Heidelberg (Germany), in the first semester of 2016 and received generous and critical assistance from Wolfgang Schluchter and Gert Albert, whom I thank for their encouragement and collaboration. I also thank the Department of Sociology and Political Science of the Federal University of Santa Catarina, which granted me the leave necessary to conclude this research, and the National Council for Scientific and Technological Development (CNPq), which supported it.

2 The complex process of redacting Economy and Society and its organization into two major phases is a topic widely discussed in the specialized literature. Even the Max Weber Gesamtausgabe collection dedicated a volume exclusively to this issue, uniting commentaries and documents (Weber, 2009). The topic has been followed closely in Brazil and there exist a number of excellent publications on the theme, including Pierucci (2008) and Lepsius (20I2).

3 In Brazil, many still know this text through the title and translation given by Mills and Gerth: "The social psychology of world religions" (Weber, I982). In relation to the theme of domination, it should be emphasized that in this first version, Weber begins his exposition with the charismatic form of domination, before examining the traditional and bureaucratic types. In all the other presentations, by contrast, the sequence is the one known to us: legal, traditional and charismatic.

4 There is also a terminological change: instead of traditionelle or tradionalistische, Weber begins to employ the term traditionale only.

5 Amid these terminological innovations, it is worth noting the novelty of the categories 'gerontocracy' and 'sultanism,' both absent from the earlier writings.

6 The expression 'estate-type patrimonialism' would only be used one more time in the post-war chapters of the sociology of domination in a context in which, discussing England, Weber declares that there it involved a combination of this form of patrimonialism and the administration of territorial lords (Weber 2005: 359). Additionally, in the Feudalism manuscript, Weber still works with the cate- 
gory 'patriarchal patrimonialism,' although the formula is not found in the manuscript entitled Patrimonialism.

7 The typology of feudalism is extremely complex since in this version (Weber, 2005: 384-385) Weber distinguishes three subtypes of feudal relations with their specific divisions: liturgical feudalism, patrimonial feudalism and free feudalism, the latter subdivided into retinue, prebendalism, vassalage and also urban feudalism. Needless to say, for Weber feudalism does not designate a mode of production but a historically determined form of domination. For a review of this concept in Weber's work, see Breuer (I988).

8 The work was finally translated and published in Portuguese by Editora Vozes and is available to Brazilian readers. The chapter on patrimonialism is found in Weber, 2016: IIO-I40).

9 It is not, therefore, through the category 'sultanism' that Weber seeks to elucidate the status of the political order in classic Chinese civilization. Hence the attempts to connect its analysis to 'eastern despotism' (as in Farris, 2013 and Sunar, 2014), following in the wake of the critique of Orientalism (Said, 2007), are entirely misplaced.

Io I thank the reviewers and editors of the journal Sociologia \& Antropologia who, notwithstanding the investment still to be undertaken, helped me appreciate and develop the consequences of the exegetical study undertaken here in terms of comprehending the reception of Max Weber's political sociology in Brazil. Without their pertinent observations, my brief conclusions would still be far below the desirable.

\section{BIBLIOGRAPHY}

Bobbio, Norberto. (2003). Max Weber e os clássicos. In: Bobbio, Norberto \& Santillán, José Fernández (orgs.). Norberto Bobbio: o filósofo e a política. Rio de Janeiro: Contraponto, p. 93-II6.

Botelho, André. (2013). Teoria e história na sociologia brasileira: a crítica de Maria Sylvia de Carvalho Franco. Lua Nova, 90, p. 33I-366. 
Breuer, Stefan. (2006). Max Webers tragische Soziologie. Aspekte und Perspektiven. Tübingen: Mohr Siebeck.

Breuer, Stefan. (200I). "Herrschaft" in der Soziologie Max Webers. Wiesbaden: Harrassowitz.

Breuer, Stefan. (1994). Bürokratie und Charisma: zur politischen Soziologie Max Webers. Darmstadt: Wiss. Buchges.

Breuer, Stefan. (1988). Der okzidentale Feudalismus in Max Webers Gesellschaftsgeschichte. In: Schluchter, Wolfgang (ed.). Max Webers Sicht des okzidentalen Christentums. Frankfurt: Suhrkamp, p. 437-475.

Bruhns, Hinnerk. (20II). Weber's patrimonial domination and its interpretations. In: Daniel C. Bach \& Mamoudou Gazibo (eds.). Neopatrimonialism in Africa and Beyond. London/New York: Routledge, p. 9-24.

Bünger, Karl. (1977). War China ein patrimonialer Staat? Orient Extremus, 24, p. 167-178.

Campante, Rubens Goyatá. (2003). O patrimonialismo em Faoro e Weber e a sociologia brasileira. DADOS - Revista de Ciências Sociais, 46/I, p. I53-I93.

Cardoso, Fernando Henrique. (2003). Capitalismo e escravidão no Brasil Meridional. Rio de Janeiro: Civilização Brasileira.

Egger, Stephan. (2006). Herrschaft, Staat und Massendemokratie: Max Webers politische Moderne im Kontext des Werks. Konstanz: UVK.

Faoro, Raymundo (I975). Os donos do poder: formação do patronato político brasileiro. Rio de Janeiro: Globo.

Farris, Sara. (2013). Max Weber's theory of personality: individuation, politics and orientalism in the sociology of religion. Leiden: Brill.

Fernandes, Florestan (2006). A revolução burguesa no Brasil. São Paulo: Globo.

Franco, Maria Silva do Carvalho. (I976). Homens liures na ordem escravocrata. São Paulo: Ed. Unesp.

Hamilton, Gary G. (I984). Patriarchy, patrimonialism, and filial piety: a comparison of China and Western Europa. A revision of Weber's sociology of domination. Theory and Society, I3, p. 393-425. 
Hanke, Edith.(200I). Max Weber "Herrschaftsoziologie”. Eine werkgeschichtliche Studie. In: Hanke, Edith \& Mommsen, Wolfgang J.(eds.). Max Webers Herrschaftssoziologie: Studien zu Entstehung und Wirkung. Tübingen: Mohr Siebeck, p. 19-46.

Hermes, Siegfried. (2003). Soziales Handeln und Struktur der Herrschaft: Max Webers verstehende historische Soziologie am Beispiel des Patrimonialismus. Berlin: Duncker \& Humblot. Holanda, Sérgio Buarque. (I995) [1936]. Raízes do Brasil. 26 ed. São Paulo: Companhia das Letras.

Lamounier, Bolívar. (20I4). Tribunos, profetas, sacerdotes. Intelectuais e ideologias no século XX. São Paulo: Companhia das Letras.

Lepsius, Mario Rainer. (2012). "Economia e sociedade": a herança de Max Weber à luz da edição de sua obra completa (MWG). Tempo social, 24/I, p. I37-I45.

Lichtblau, Klaus. (20II). Die Beiden Soziologien Max Webers. Die Eigenart der Kultur und Sozialwissenschaftlichen Begriffsbildung. Frankfurt: VS Verlagen, p.389-396.

Lin, Duan. (1997). Konfuzianische Ethik und Legitimation der Herrschaft im alten China: eine Auseinandersetzung mit der vergleichenden Soziologie Max Webers. Berlin: Duncker \& Humblot.

Maurer, Andrea (I999). Herrschaft und soziale Ordnung: kritische Rekonstruktion und Weiterführung der individualistischen Theorietradition. Opladen [u.a.]: Westdt. Verlag.

Norkus, Zenona. (200I). Max Weber und Rational Choice. Marburg: Metropolis.

Pierucci, Antônio Flávio. (2008). Economia e sociedade: últimos achados sobre a "grande obra" de Max Weber. Revista Brasileira de Ciências Sociais, 23/68, p. 4I-5I.

Said, Edward. (2007). Orientalismo: o Oriente como invenção do Ocidente. Trad. Rosaura Eichenberg. São Paulo: Companhia das Letras.

Schluchter, Wolfgang. (20I6). Max Webers späte Soziologie. Tübingen: Mohr Siebeck.

Schluchter, Wolfgang. (I988). Religion und Lebensführung. Suhrkamp: Frankfurt a.M.. Studienausgabe ig9r. Studien zu Max Webers Kultur- und Werttheorie. Studien zu Max Webers Religions- und Herrschaftssoziologie. 
Schluchter, Wolfgang. (1985). Aspekte bürokratischer Herrschaft. Frankfurt: Suhrkamp.

Schluchter, Wolfgang. (1983). Max Webers Studie über Konfuzianismus und Taoismus: Interpretation und Kritik. Frankfurt am Main: Suhrkamp.

Schmidt-Glinzer, Helwig. (200I). China und die Angemessenheit der Begriff der "Patrimonialbürokratie". In: Hanke, Edith \& Mommsen, Wolfgang J. (eds.). Max Webers Herrschaftssoziologie: Studien zu Entstehung und Wirkung.Tübingen: Mohr Siebeck, p. 223-234.

Schwarz, Roberto. (1992). Ao vencedor as batatas. São Paulo: Duas Cidades.

Schwartzman, Simon. (I988). Bases do autoritarismo brasileiro. Rio de Janeiro: Campus.

Sell, Carlos Eduardo. (2013). Max Weber e a racionalização da vida. Petrópolis: Vozes.

Souza, Jessé. (2015). A tolice da inteligência brasileira: ou como o país se deixa manipular pela elite. São Paulo: LeYa.

Sunar, Lütfi. (20I4). Marx and Weber on oriental societies: in the shadow of western modernity. Farnham: Ashgate.

Villas Bôas, Glaucia. (20I4). A recepção controversa de Max Weber no Brasil (I940-I980). DADOS - Revista de Ciências Sociais, 57/I, p. 5-33.

Weber, Max (2016). A ética econômica das religiões mundiais. Confucionismo e taoísmo. Petrópolis: Vozes.

Weber, Max. (2013). Wirtschaft und Gesellschaft. Soziologie (I9I9-I920). In: Borchardt, Knut; Hanke, Edith \& Schluchter, Wolfgang (eds.) Max Weber Gesamtausgabe I/23. Tübingen: Mohr Siebeck.

Weber, Max. (2009). Wirtschaft und Gesellschaft. Entstehungsgeschichte und Dokumente. In: Schluchter, Wolfgang (ed.). Max Weber Gesamtausgabe I/24. Tübingen: Mohr Siebeck.

Weber, Max (2005). Wirtschaft und Gesellschaft. Herrschaft. Hanke, Edith \& Kroll, Thomas (eds.). Max Weber Gesamtausgabe I/22-4. Tübingen: Mohr Siebeck.

Weber, Max (2003). Briefe I9I3-I9I4. Lepsius, M. Rainer et al. (eds.) Max Weber Gesamtausgabe II/8. Tübingen: Mohr Siebeck. 
Weber, Max. (1996). Die Wirtschaftsethik der Weltreligionen. Hinduismus und Buddhismus I916-1920. In: Helwig Schmidt-Glintzer (ed.). Max Weber Gesamtausgabe I/20. Tübingen: Mohr Siebeck.

Weber, Max. (I989). Die Wirtschaftsethik der Weltreligionen. Konfuzianismus und Taoismus. Schriften I9I5I920. Schmidt-Glintzer, Helwig \& Kolonko, Petra (eds.). Max Weber Gesamtausgabe I/ı9. Tübingen: Mohr Siebeck.

Weber, Max. (1982). A psicologia social. In: Mills, C. Wright \& Gerth, Hans Heinrich. (eds.). Ensaios de sociologia. Rio de Janeiro: LTC, p. I26-I37.

Werneck Vianna, Luiz. (I999). Weber e a interpretação do Brasil. Novos Estudos Cebrap, 53, p. I-I5.

Zabludovsky, Gina Kuper. (1989). La dominación patrimonial en la obra de Max Weber. Cidade do México: Fondo de Cultura Econômica.

Zingerle, Arnold. (1972). Max Weber und China. Herrschaft und religionssoziologische Grundlage zum Wandel der Chinesinnen Gesellschaft. Berlin: Duncker \& Humblot. 


\section{OS DOIS CONCEITOS DE PATRIMONIALISMO EM MAX WEBER: DO MODELO DOMÉSTICO AO ORGANIZACIONAL \\ Resumo}

O objetivo do artigo é atualizar a discussão exegética sobre o conceito de patrimonialismo nos escritos sociológicos de Max Weber. Acompanhando os resultados da republicação das obras weberianas, discute-se a evolução da sociologia da dominação nas diferentes fases de redação de Economia e sociedade, com especial ênfase nas modificações introduzidas no tipo tradicional de dominação. A partir da história da obra distinguem-se os dois modelos conceituais de patrimonialismo que se sucedem em seus escritos: o doméstico e o organizacional. Do ponto de vista sistemático, esses modelos serão detalhados em sua natureza teórica (tipo ideal) e como instrumentos comparativos de análise socioempírica. Ao final, em afinidade com os modelos de Weber, caracterizam-se duas concepções típico-ideais de patrimonialismo presentes no debate brasileiro: a concepção sociopatriarcal e a concepção institucional-liberal.

\section{THE TWO CONCEPTS OF PATRIMONIALISM IN MAX WEBER: FROM THE DOMESTIC MODEL TO THE ORGANIZATIONAL MODEL}

Abstract

The aim of this article is to update the exegetical discussion of the concept of patrimonialism in the sociological writings of Max Weber. In the wake of the results of the latest publication of his works, it discusses the evolution of the sociology of domination in the different stages of writing of Economics and society, with special emphasis on the changes that Weber introduces to the traditional type of domination. Focusing on the history of the work, two conceptual models of patrimonialism are distinguished that follow each other in his writings: the domestic model and the organizational model. From a systematic point of view, these models will be detailed in their theoretical nature (ideal-type) and as comparative instruments of socio-empirical analysis. In the conclusion, and in affinity with Weber's models, two ideal-typical conceptions of patrimonialism present in the Brazilian debate are characterized: the socio-patriarchal and the institutional-liberal conceptions.
Palavras-chave

Max Weber; poder; dominação; patrimonialismo; patrimonialismo Estamental.

Keywords

Max Weber; power; domination; patrimonialism; estate-type patrimonialism. 